Paideusis

\title{
"Between Caring and Counting: Teachers Take on Education Reform" (Lindsay Kerr)
}

\section{Sarah Elizabeth Barrett}

Volume 16, Number 1, 2007

URI: https://id.erudit.org/iderudit/1072608ar

DOI: https://doi.org/10.7202/1072608ar

See table of contents

Publisher(s)

Canadian Philosophy of Education Society

ISSN

0838-4517 (print)

1916-0348 (digital)

Explore this journal

Cite this review

Barrett, S. (2007). Review of ["Between Caring and Counting: Teachers Take on Education Reform" (Lindsay Kerr)]. Paideusis, 16(1), 61-65.

https://doi.org/10.7202/1072608ar

This document is protected by copyright law. Use of the services of Erudit (including reproduction) is subject to its terms and conditions, which can be viewed online.

https://apropos.erudit.org/en/users/policy-on-use/ 
Review of

\title{
Between Caring and Counting: Teachers Take on Education Reform
}

by Lindsay Kerr, Toronto: University of Toronto Press, 2006

\author{
SARAH ELIZABETH BARRET'T \\ University of Western Ontario, Canada
}

Between Caring and Counting centres around the Ontario education system between 1995 and 2003. This was a time of major upheaval in Ontario's health, welfare and education systems, instigated by the provincial Progressive Conservative Party's proclaimed Common Sense Revolution. The study is what the author calls an ethnography (though I am not so sure that that is what it is) based on a group of four high school teachers and their experiences during a time of unprecedented funding cuts $(\$ 1$ billion was removed from the education system) and policy change. I approached this book with some trepidation, having lived through the era myself as a high school teacher. As a member of a branch executive in OSSTF, I was actively involved in the political struggle at the school level. I was the proud recipient of two threatening letters from the Ontario College of Teachers with respect to my noncompliance with the Professional Learning Program (PLP). Also, for my Masters research, I, too, did a study about a small group of teachers struggling with the "new regime" as they wrote a curriculum that was apparently contrary to the philosophy of social reproduction that was undeniable at the time. Since then, I have briefly worked at the Ontario College of Teachers as a research assistant - an eyeopening experience - and am currently teaching in a preservice teacher education program. I relate all of this to the reader to provide a sense of my own perspective as I read this book. I am not sure it was possible for me to disagree with Kerr's final conclusions. Having said this, there is always room for critique.

The book begins with the defeat of Ontario's Progressive Conservative party in 2003 and a recognition of the pervasive nature of neoliberal ideology. As Kerr puts it:

The ideology that underpins neoliberal policies extends across political parties and has a scope far beyond Ontario; it has a long history and a global geographical reach. (p. 4)

This is a key point in the book. A second main argument is that the ethic of care that imbues education is used to manipulate and exploit teachers. Kerr ties this into the idea that since the teaching profession is comprised mostly of women in the classroom and men in administration, a patriarchal structure exists which essentializes and objectifies teachers. Rather than being viewed as agents within the system, teachers are viewed simply as another factor in the equations of management. Through analysis of focus group transcripts and textual analysis of four texts (the report of the Royal Commission on Learning, a letter from the Ontario College of Teachers (OCT) to all members describing the Professional Learning Program (PLP) that had been mandated by government, and two

(C) Copyright 2007. The author, Sarah Elizabeth Barrett, assigns to Paideusis the right of first publication and educational and non-profit institutions a non-exclusive license to use this document for personal use and in courses of instruction provided that the article is used in full and this copyright statement is reproduced. Any other usage is probibited without the express permission of the author. 
texts from the Toronto District School Board (TDSB)), Kerr attempts to develop what she calls an institutional ethnography of the education system. I believe the underlying philosophy of her approach is stated succinctly in chapter 4:

The 'analysis of descent' begins with discerning contradictions between what the ruling structure say they do and how teacher-participants perceive them. (p. 50)

This book is based on Kerr's Masters thesis and is structured accordingly. In Chapter 1, she describes her objectives in the following way:

To identify the 'ruling structures' that control the everyday work and lives of teachers in the public education system; to analyse and map the 'ruling relations' that operate within the public education system; and to identify the ideological code constitutive of the education system under reform. (p. 4)

She describes the political situation locally and globally that gave rise to those objectives, as well. Chapter 2 is a genealogy of the Ontario Progressive Conservative government's ideology, tracing it from the report of the Royal Commission on Learning which was created by the Ontario New Democratic government in 1994. Chapter 3 describes her methodology. Chapter 4 introduces the reader to the "ruling structures" in teachers' lives and how they relate to one another. Chapter 5 focuses on three texts which she sees as indicative of the power relations and underlying ideology of the Ontario education system. The final chapter attempts to describe where one goes from here.

Kerr is at her best when she is describing the experiences of the members of the focus group, as they attempt to make sense of policy directions from their school board while continuing to do what they think is best for their students. I found myself wishing there could be more quotes from this discussion to put the macro analysis of ruling structures into perspective. Kerr has an excellent ability to relate the personal experiences of the participants to the larger political context. She is equally good at tracing the relations of individuals at the "upper echelons" of structures in education and relating this back to the bigger picture. Where Kerr is weak, and this is my biggest complaint with this book, is with respect to the actual educational structures she targets - the Ontario College of Teachers (OCT), Education Quality and Accountability Office (EQAO), Ontario Principals' Council (OPC), Toronto District School Board (TDSB), Royal Commission on Learning, Ontario Secondary School Teachers Federation (OSSTF), Ontario Parent Council, Ontario Teachers Federation (OTF) and the Ministry of Education and Training (The Ministry). Once individuals are removed from her analysis, all of the individuals within these ruling structures are denied agency. Kerr fails to recognize that teachers were not necessarily the only ones forced by policy to act in ways in which they did not feel comfortable other individuals in other structures likely suffered the same fate. This may not have been obvious to the teachers with whom she spoke in the focus group, but as an inside-outsider herself, she is in a position to recognize this. Instead, interpretations become black-and-white, good guys and bad guys, with no nuance. The Ministry is depicted as all-powerful and all-knowing through its conspiratorial arms, and no independent thought is attributed to anyone but the evil Ministry and the angelic teachers. The OCT and OPC, for example, are depicted as arms of government, each of which subscribe to white male values (which she never defines). Her analysis of these bodies is also very simplistic. For example, website links between OCT, EQAO and the Ontario Parent Council are interpreted as "suggesting that they operate in concert to enforce compliance with legislation" (p. 52). A login on the OPC website is regarded with suspicion. She notes that the OCT's request to the government for funds to administer the PLP (a government program that the OCT was forced to implement) ${ }^{1}$ is

\footnotetext{
1 Personal contacts within the OCT complain to this day that the Professional Learning Framework and
} Standards of Practice were co-opted by the government in ways that the OCT had never intended (the PLP and 
evidence that they are closely aligned with them.

It would be an interesting line of inquiry if Kerr made parallels between (1) the ways in which teachers were placed in a double bind because of their being employees of a system that they felt was harming the students they worked with and (2) the position of the OCT and OPC, attempting to work with a government which had made it clear that critique would be punished and suggestions would be ignored unless they were what the government had already decided. During the time in question, these admittedly patriarchal structures were left in a strange position where they had to flatter, cajole and scheme to have any influence on policy, in much the same way as women have historically had to do to influence men. The token participation described with respect to individuals in Kerr's Afterword is characteristic of relations at the institutional level as well.

I am not suggesting for a moment that neoliberal ideology does not permeate the upper echelons of education or that Kerr is incorrect in stating that the OPC, OCT, EQAO and Royal Commission on Learning intended to restructure education to fit the globalization agenda. What I am saying is that the relations were much more complex than described, since individuals within these bodies were much more diverse than Kerr lets on. Consequently, I believe this study is a largely phenomenological account from the perspective of classroom teachers. Using phrases like "they thought," "they perceived as," "it seemed to them" might have excused some of the errors and omissions that are scattered throughout ${ }^{2}$ because, in a phenomenological account, it would be the teachers' reactions and perceptions that are important, not what is actually the case. But Kerr does not make such distinctions and this weakens her arguments somewhat.

This brings me to a technical critique of the study. It is not an ethnography. There is none of the rich description required to really convey the culture of the institution of education in Ontario. A visit to a lobby or web site hardly provides enough data to do an ethnographic analysis, and calling it an ethnography distracts the reader from the stronger parts of her methodology - those grounded in the experiences of the four teachers in the focus group.

Finally, in the Afterword, Kerr seems to conflate teachers' rejection of the education reforms forced on the system - through new regulations, the removal of funding and the imposition of unprecedented teacher surveillance and control - with a desire on the teachers' part to put forward a social justice agenda. I believe that the neoliberal understanding of the world is as pervasive within the ranks of teachers as it is anywhere else. It is unlikely that principals suddenly transformed into neoliberal ideologues when they were legislatively removed from the teacher federations and the OPC was formed. And I suspect that the OTF will not miraculously change into a grassroots organization (as Kerr suggests) if the OCT is dissolved. I know this from Kerr's own analysis. She describes a reality in which institutions have a life of their own that, I believe, sometimes seems to go in a direction different than the individuals within them would wish them to take. This is not to deny agency or responsibility to those within, but rather to acknowledge that institutions have momentum and this momentum often goes beyond the will of the workers on the ground. Thus, we have the all too common situation where the less powerful, even when they think they have joined the winning team, are still left out in the cold, less able to make a difference than they had hoped. In a similar way, classroom teachers are very much part of the system Kerr critiques, regardless of their intentions.

The institution of education, through the ruling structures Kerr highlights and through classroom teachers themselves, performs its social reproductive function very well, sorting students into the categories of smart-not smart, privileged-not privileged, powerful-not powerful - reinforcing social inequities as it does so. Admittedly, teachers and other educators have made attempts over the

TPA respectively). The OTQT was a similar betrayal in their eyes. See Ontario College of Teachers, "Maintaining, Ensuring and Demonstrating Competency in the Teaching Profession: The College Responds to the Minister of Education's Proposal for a Teacher Testing Program," (Toronto: Ontario College of Teachers, 2000).

${ }^{2}$ Especially with respect to the legislation and regulations which affected all of the ruling structures she highlights. 
last forty years to mitigate the unfair aspects of the system through, for example, special education, vocational schools, comprehensive high schools, reading recovery and the common curriculum. Yet, perhaps with the exception of special education programs which came into being largely through the advocacy of parents, educators have failed to consult with those whom the programs were designed to serve. Kerr notes that newly legislated bodies such as Parent Councils are not true consultation bodies, because of systemic barriers:

Few parents have the time to volunteer, with the result that the burden falls on a few committed ones who tend to represent the interests of a small segment of the school population - typically the privileged white middle/upper-middle class. Parents tend to emphasize the needs of their own children over those of the student body at large. The interests of non-dominant groups (such as immigrants, single-parent families, lower socioeconomic groups), for whom systemic barriers to participation exist (such as language, shift work, double jobs, or lack of daycare) are rendered invisible in school decision-making. (p. 78)

Kerr seems to imply that Parent Councils are therefore just another ruling structure with which teachers must contend, cut from the same cloth as the OCT - another representative body that fails to represent - and impeding the good work of the teacher. Yet, immigrants, single-parent families and those in lower socio-economic groups have always been marginalized within the school system, even prior to Parent Councils, OCT, OPC and the Common Sense Revolution, and even during the time in Ontario when there was a great deal of local control and teacher autonomy in education. Kerr misses a golden opportunity to bring to the fore teachers' complicity in the system in which we work.

Therefore, I would like to offer a supplemental and quite cynical conclusion to Kerr's analysis, one which I admit is based solely on my own experience. I believe the education reforms that came to a head between 1995 and 2003 were so traumatic for teachers because teachers and educators were officially frozen out. Almost no educators (whether classroom teachers, principals or employees within ruling structures - including the Ministry) were actually sincerely consulted during those years. ${ }^{3}$

Interestingly, the education reforms of 1995-2003 were possibly the first time that educators at all levels experienced the ways in which many parents and students in marginalized groups had felt for years - patronized, irrelevant, and disposable. Kerr's account of this loss of innocence is compelling indeed.

\section{References}

Dornbusch, Sanford M., Kristan L. Glasgow, and I-Chun Lin. "The Social Structure of Schooling." Annual Review of Psychology 47 (1996): 401-29.

Glesne, Corrine. Becoming Qualitative Researchers : An Introduction. 2nd ed. New York: Longman, 1999.

Ontario College of Teachers. "Maintaining, Ensuring and Demonstrating Competency in the Teaching Profession: The College Responds to the Minister of Education's Proposal for a Teacher Testing Program." Toronto: Ontario College of Teachers, 2000.

Weber, Ken, and Sheila Bennett. Special Education in Ontario Schools. Thornhill, Ontario, Canada: Highland Press, 1999.

Winter, Eileen C., and William R. McEachern. "Dealing with Educational Change: The Ontario Experience." Education and Urban Society 121, no. 4 (2001).

\footnotetext{
${ }^{3}$ For a description of the way that the reforms were implemented in Ontario, see Eileen C. Winter and William R. McEachern, "Dealing with Educational Change: The Ontario Experience," Education and Urban Society 121, no. 4 (2001).
} 
Wollstonecraft, Mary. "A Vindication of the Rights of Men; a Vindication of the Rights of Women." In A Wollstonecraft Anthology, edited by Janet Todd, 64-114. New York: Columbia University Press, 1790. 